\title{
Türk Sermaye Piyasasında Kuşaklar Arasında Yatırımcı ve Portföy Farklılıkları
}

Aysel Gündoğdu

\author{
Şaban Çelik ${ }^{2}$
}

Öz

Kuşaklar arasındaki farklılıklar ekonomik ve sosyal açıdan bireylerin davranışlarında değişikliklere sebep olabilmektedir. Kuşakların zaman içerisinde farklılaşan özellikleri finansal bir yatırımdan beklentilerini, bu finansal yatırım için katlanabildikleri risk seviyesini değiştirebilmektedir. Çalışmanın amacı Türk sermaye piyasasında Kuşaklar Arasında Yatırımcı ve portföy Farklıklarını belirlemektir. Çalışmada yedi adet hipotez ki kare testi, kruskal wallis testi, çift yönlü ANOVA yöntemine göre test edilmiştir. Yapılan analizin sonuçlarına göre; kuşaklar arasında yatırımcı sayıları ve portföy değerleri farklılaşmaktadır. Buna karşın kuşaklar arasındaki menkul kıymet dağılımı istatistiksel olarak anlamsızdır. Kuşak ve kıymet türü değişkenleri yatırımcıların portföy değerleri ve sayılarını açıklamada önemli faktörler olduğu sonucuna varılmıştır.

\author{
Anahtar Sözcükler \\ Yatırımcı • Sermaye piyasası • Risk tercihi
}

\section{Investor and Portfolio Differences between Generations in Turkish Capital Markets}

\section{Abstract}

Generation may lead to differences in the number of individuals in the behavior of economic and social values. The characteristics of the generations can change the expectations of a financial investing and the level of risk. The aim of the study is to determine the investor and portfolio differences between generations in the Turkish capital market. In the study, seven hypotheses were tested according to the chi square test, the kruskal wallis test, and the two-way ANOVA method. According to the results of the analysis; the number of investors and portfolio values differ among generations. In contrast, securities distribution among generations is not statistically significant. It is found that generation and security type as a factor play a significant role in explaining portfolio values and number of investors.

\section{Keywords}

Investor • Capital market • Risk tolerance

Yatırımcıların finansal kararlarında etkili olan bazı özellikler mevcuttur. Yatırımcının erkek mi kadın mı olduğu, yaşlı mı genç mi olduğu, yükseköğretim görüp görmediği ve gelirinin seviyesine göre yatırım davra- nışlarında farklılıklar görülmektedir. Sosyolojik açıdan belirli yaş gruplarına denk düşen "kuşak"ların da yatırım kararlarında etkili olup olmadığı araştırılmaktadır. Genel kabul görmüş bu kuşakların her toplumda

\footnotetext{
1 Sorumlu Yazar: Aysel Gündoğdu (Doç. Dr.), İstanbul Medipol Üniversitesi, İşletme ve Yönetim Bilimleri Fakültesi, Bankacılık ve Sigortacılık Bölümü, İstanbul Türkiye. Eposta: agundogdu@medipol.edu.tr

2 Şaban Çelik (Dr. Öğr. Üyesi), İzmir Katip Çelebi Üniversitesi, İşletme Bölümü, İzmir, Türkiye. Eposta: saban.celik@ikc.edu.tr

Atıf: Gündoğdu, A. ve Çelik, Ş. (2018), Türk sermaye piyasasında kuşaklar arasında yatırımcı ve portföy farklılıkları. Istanbul Business Research, 47(1), 49-66. http://dx.doi.org/10.26650/ibr.2018.47.1.0003
} 
farklı davranışlara sebep olmasının yanı sıra genellikle son yüzyılda küreselleşmenin ve teknolojinin de gelişmesi ile birlikte insanların geçmişe göre daha benzer davranışları sergiledikleri gözlemlenmektedir. Ancak kuşakların özellikle finansal kararlarda ve risk alma konusunda farklı davrandıkları da bilinmektedir. 21. Yüzyıl öncesi toplumlar daha kapalı bir yapıya sahip iken günümüzde yaşayan kuşaklar olan sessiz kuşak, bebek patlaması kuşağı, $\mathrm{X}, \mathrm{Y}$ ve $\mathrm{Z}$ kuşaklarının farklı davranışları olduğu ampirik çalışmalarda ortaya konulmuştur.

Sessiz Kuşak, bebek patlaması kuşağı, $X$ ve $Y$ kuşaklarının farklı sosyo-kültürel ve teknolojik çağları yaşamış olmaları, sözkonusu kuşakların tutumlarında ve beklentilerinde farklıliklara sebep olmuştur. (Ayhün: 2013:95) Bu farklılıkların kuşakların finansal yatırımlarında ve finansal risk toleranslarında da farklılığa sebep olup olmadığı literatürde bir araştırma konusunu oluşturmuştur.

Yatırımcının riski ne ölçüde kabul edebildiği, onun risk toleransını göstermektedir. Bireyin risk toleransı azaldıkça, yaptığ riskli yatırımlar da ona bağlı olarak azalacaktır. Bu sebeple risk tolerans1, yatırımciların finansal kararlar alırken gösterdikleri davranışlarını açıklayan, bireylerin risk karşısındaki tutumlarını ve ne kadar risk almaya hazır bulunduğunu gösteren önemli kavramlardan biridir. (Tanyolaç ve Karan; 2015: 681) Grable (2000) ise finansal risk toleransinı "yatırmominin finansal karar verirken kabul etmeye istekli olduğu azami belirsizlik miktarı" şeklinde tanımlamıştır.

Demografik ve sosyoekonomik değişkenler ile bireyin finansal risk toleransı ara- sında yakın bir ilişki olduğu varsayılmakta ve bu değişkenlere göre yatırımcıların risk profilleri çıkarılmaya çalışılmaktadır. Finansal risk toleransı ile demografik ve sosyoekonomik özellikler arasındaki ilişkiler açısından genel kabul gören görüşlere göre yatırımcının yaşı arttıkça finansal risk tolerans1 azalmaktadır. (Anbar ve Eker; 2009:144) Yatırım danışmanları, yatırımcının yaşını finansal varlıklarının amaç ve hedeflerini karşılaması için gerekli olan sürenin ölçüsü olarak kullanırlar. Yaşı bireylerin genç bireylere göre daha az yaşam süresi kaldığ 1 için yaşlı bireylerin daha düşük risk toleranslarına sahip olacağı yaygin olarak kabul edilmektedir. (Grable; 1997: 14) Genç yatırımcıların yaşam süresi yaşlı yatırımcılara göre daha uzun olması beklendiğinden gençlerin hisse senetleri piyasası uzun vadede daha yüksek getiri sağlayabileceği için hisse senedi yatırımına yönelmelerinin daha rasyonel olması düşünülmektedir. Genç yatırımcıların risk gerçekleştiğinde kayıplar ile daha fazla mücadele etmesi beklenir. (Jagannathan ve Kocherlakota; 1996:20)

Bireylerin yatırım alışkanlıkları ve yatırımda riske yaklaşımı yaş, cinsiyet ve eğitim açısından farklılıklara sebep olabilmektedir. Yatırımciların demografik ve sosyolojik değişkenleri ile finansal risk toleransları arasındaki çalışmalara bakıldığında genel olarak şu sonuçlara varılmıştır (Roszkowski; 1993:10).

- Erkek yatırımcıların risk toleransı kadın yatırımcılara göre daha yüksektir.

- Genç yatırımcıların risk toleransı yaşlı yatırımcilara göre daha yüksektir. 
- Bekar yatırımcıların risk toleransı evli yatırımcilara göre daha yüksektir.

- Mesleki işlerde çalışan yatırımcıların risk toleransı mesleki olmayan işlerde çalışan yatırımcılara göre daha yüksektir.

- Serbest çalışan yatırımcıların risk toleransı istihdamlı çalışan yatırımcılara göre daha yüksektir.

- Yüksek gelirli yatırımciların risk toleransı daha düşük gelirli yatırımcılara göre daha yüksektir.

- Daha yüksek eğitimli yatırımcıların risk toleransı daha düşük eğitimli yatırımc1lara göre daha yüksektir.

Çalışmada Türk sermaye piyasasında Sessiz, Bebek, X, Y kuşaklarının finansal yatırım eğilimleri ve risk toleransları incelenmiştir. Kuşaklara göre yatırım araçlarının türlerine ne kadar yatırım yapıldığ 1 ortaya konulan çalışmada böylelikle kuşakların finansal risk toleransı arasındaki farklılıklar incelenmiştir. Çalışmanın ilk bölümünde Türk sermaye piyasasında yatırımc1 profili, ikinci bölümde kuşaklar ve risk tercihlerine yer verilmiştir. Çalışmada kullanılan veriler, Merkezi Kayıt Kuruluşu'ndan alınmıştır.

\section{Literatür Taraması}

Yatırımcıların yaşı, yatırım beklentileri, risk algıları ve buna benzer finansal ilişkilerin incelendiği çalışmalar literatürde çok sayıda araştırmada mevcuttur. Ancak yaş faktörünü kuşaklar açısından değerlendiren çalışma yok denecek kadar azdır. Bu nedenle çalışmanın literatüre katkıda bulunacağı beklenilmektedir.
Yatırımcının yaşı ile risk toleransı arasında negatif ilişki olduğu genel kabul gören bir yaklaşımdır. Diğer bir ifade ile genç yatırımcılar yaşlı yatırımcılara göre daha yüksek risk almaya eğilimlidirler (Grable; 2008: 25). Ampirik çalışmalarda bu yaklaşımı destekleyen çalışmalar bulunmaktadır. Yatırımcının yaşı ile risk toleransı arasındaki ilişkiyi inceleyen ilk çalışma Wallach and Kogan (1961) olarak kabul edilmektedir. Çalışmada yaşlı bireylerin gençlere göre daha az risk toleransının olduğu ortaya çıkarılmış, bu çalışmadan sonra araştırmacıların ilgisi bu konu üzerine yoğunlaşmıştır. Vroom ve Pahl (1971); Bossons (1973); Okun ve DiVesta (1976); McInish (1982); Morin ve Suarez (1983); Hawley ve Fujii (1993-1994); Bakshi ve Chen (1994) çalışmalarında daha yaşlı yatırımcıların risk toleransının gençlere göre daha düşük olduğu sonucuna ulaşmıştır.

Daha güncel çalışmalara bakılırsa; Bali vd. (2009) çalışmalarında yatırımcıların yaşı ile hisse senedi ve tahvil yatırımlarına yapılan yatırım oranları arasındaki ilişkiyi incelemişlerdir. Genç yatırımcıların daha çok hisse senedine yatırım yaptıkları, yaş ilerledikçe tahvile yöneldikleri sonucuna ulaşmışlardır. Yao vd. (2011); Sachse vd. (2012) çalışmalarında risk toleransının yatırımcının yaşı arttıkça azaldığı ancak kuşaklar arasındaki farkın risk toleransı üzerinde etkili olmadığı sonuca varmışlardır. Usul vd. (2002) çalışmalarında yaşlı yatırımcıların gençlere oranla hisse senetlerini çabuk elden çıkarma eğiliminde olduklarını, yaşlı yatırımcıların gençlere oranla riskten kaçındıklarını ortaya koymuşlardır. 
Davydos vd. (2017) yatırımcıların yaşı ile aldıkları risk arasında negatif yönlü bir ilişki olduğunu ancak yatırımcıların yaşı arttıkça portföylerinde daha yüksek getiri elde ettikleri bulgusuna varmışlardır. Kesbiç ve Yiğit (2016) çalışmasında yatırımcıların yaşının artması ile aldıkları riskin azaldığı bulgusuna rastlanmaktadır. Yeşildağ vd. (2017) çalışmasında hisse senedi yatırımcılarının yaş aralı̆g 1 arttıkça sahip olunan portföy büyüklüğünün de arttığ1 sonucuna ulaşmıştır. Brooks vd. (2018) yatırım danışmanlarının yatırımıının riske yönelik tutumunu ölçmek için yaptığı testler doğrultusunda yatırımcının yaşı ile risk toleransı arasında ilişki olup olmadığını incelemişlerdir. Çalışmanın sonucuna göre nispeten yaşlı yatırımcılar daha düşük riskli finansal araçlara yönelmektedirler.

Diğer yandan yatırımcının yaşı ile risk toleransı arasında pozitif ilişki olduğunu ortaya koyan ya da yatırımcının yaşı ile risk toleransı arasında anlamlı bir ilişkiye rastlamayan çalışmalar da mevcuttur. Grable (2000) çalışmasında yaşlı yatırımcıların gençlere göre daha fazla risk toleransı olduğunu ortaya koymuştur. Saraç ve Kahyaoğlu (2011) farklı yaş gruplarındaki bireysel yatırımcılar arasında risk alma eğilimi açısından anlamlı bir fark olduğu, yaşlı yatırımcıların risk alma eğiliminin genç yatırımcılardan yüksek olduğu sonucuna varmışlardır. Sulaiman (2012) çalışmasında yaş artışının bireysel yatırımcının finansal risk toleransını arttırdığı sonucuna ulaşmıştır. Tanyolaç ve Karan (2015) da daha yaşlı olan yatırımcıların daha fazla risk aldığını ve menkul kıymet yatırımı yaptığını ortaya koymuşlardır. Hallahan vd. (2003) ise yatırımciların finansal risk toleransi ile demografik özellikleri arasındaki ilişkiyi ince- lemişlerdir. Yapılan araştırmaya göre yatırımcının yaşı ile risk toleransı arasında anlamlı bir ilişki bulunmamaktadır. Ameriks ve Zeldes (2004) ; Alpay vd. (2015) de yatırımciların yaşı ile finansal yatırımlarda aldıkları risk arasında bir ilişkiye rastlamamıştır.

Yatırımcının yaş faktörü ile risk toleransı arasındaki ilişkiyi inceleyen çalışmalar d1şında yatırımcının ait olduğu kuşak ile yatırım tercihleri arasındaki ilişkiyi inceleyen çalışmalara da rastlanmaktadır. Örneğin; Çiftçi (2017) çalışmasında Türkiye'deki Jenerasyon Y'nin yatırım tercihleri oyun teorisi ile tahmin etmiştir. Araştırmanın sonucunda Jenerasyon Y'nin en çok tercih ettiği yatırım aracının altın olduğu ortaya çıkmıştır. Wang (2011) yatırım yapan genç kuşakların davranışlarını incelemiştir. Çalışmada genç kadınların servet yönetiminde zorlandıkları sonucuna ulaşmıştır.

Literatür incelemesinde yatırımcinın yaşı ile risk toleransı arasında bir ilişki olduğunu gösteren kanıt niteliğinde çok sayıda çalışma vardır. Genel görüş, yatırımcının yaşının arttıkça risk toleransının azaldığı yönündedir. Bu çalışmanın hipotezini ise daha yeni kuşakların eski kuşaklara göre daha yüksek risk toleransına sahip olduğu oluşturmaktadır.

\section{Türk Sermaye Piyasasında Yatırımcı Profili}

Türkiye'de yurtiçi yerleşiklerin tasarruf toplamı 2017 yılının Eylül ayı itibari ile 2,2 trilyon TL olup toplam tasarrufların \%69'u mevduata, \%26's1 tahvil-bonoya, \%5'i ise pay senedine yatırılmaktadır. Buna karşıllık 
Türk sermaye piyasalarında yatırım yapan yurtdışı yerleşiklerin toplam tasarrufu 458 milyar TL olup bu tutarın \%27'si mevduata, $\% 28$ 'i tahvil-bonoya ve $\% 46$ 's1 pay senedine yatırılmaktadır. (TSPB; 2017: 56-58) Grafik 1'de görüldügüü üzere yurtiçi ve yurtdış1 yerleşiklerin yatırım yaptıkları finansal araçlar incelendiğinde yurtiçi yerleşiklerin riski sevmediği ve sabit getirili yatırım araçlarına yöneldiği; yurtdışı yerleşiklerin ise riskli bir yatırım olarak kabul edilen pay senedine yöneldiği görülmektedir.

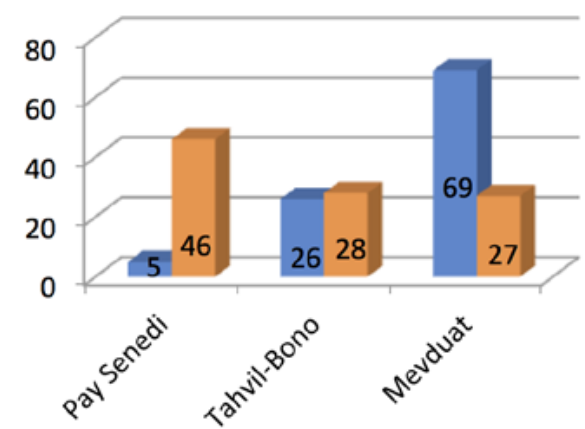

অurtiçi Yerleşik $\quad$ Yurtdışı Yerleşik

Grafik 1

Türk Sermaye Piyasasında Yatırım Tercihleri (2017/9 itibariyle)

Kaynak: TSPB, Türkiye Sermaye Piyasaları, Aralık 2017, ss.56-57, https://www.tspb.org.tr/wp-content/uploads/2015/07/Turkish-Capital-Markets-2017-12-TR. pdf, (02.04.2018)

Türk sermaye piyasasında toplam yurtiçi pay senedi yatırımcısı 2017 yılı Eylül ayı itibari ile 1.037.400 kişi olup \%99'u bireysel yatırımcıdan oluşmaktadır. Toplam yurtdışı yerleşik pay senedi yatırımcı sayısı ise 9500'dür. Yurtdış1 yerleşik yat1rımc1 sayısı bu denli az olmasına rağmen pay senedindeki toplam yatırımları, yurtiçi yerleşik yatırımcının pay senedine yaptı- $\breve{g} 1$ toplam yatırımı iki katıdır. Özel sektör borçlanma aracına yatırım yapan yatırımcı sayısı yurtiçi yerleşiklerde 85 bin, yurtdışı yerleşiklerde ise 582'dir. 2017 y1lı Eylül ayı itibari ile Türkiye'de özel sektör borçlanma aracina yapılan toplam yatırım tutarı 59,5 milyar TL'dir. 2017 yılı Eylül ayı verilerine göre yatırım fonuna yapılan toplam portföy değeri 52,7 milyar TL olup toplam yatırımcı sayısı 2,96 milyon kişidir. Özel emeklilik sisteminde 6,8 milyon, otomatik katılım sisteminde 3,3 milyon katılımc1 bulunmaktadır. Özel emeklilik sisteminde toplam portföy büyüklüğü 73,1 milyar TL, otomatik katılım sisteminde ise 2,4 milyar TL'dir. (TSPB; 2017: 59-67)
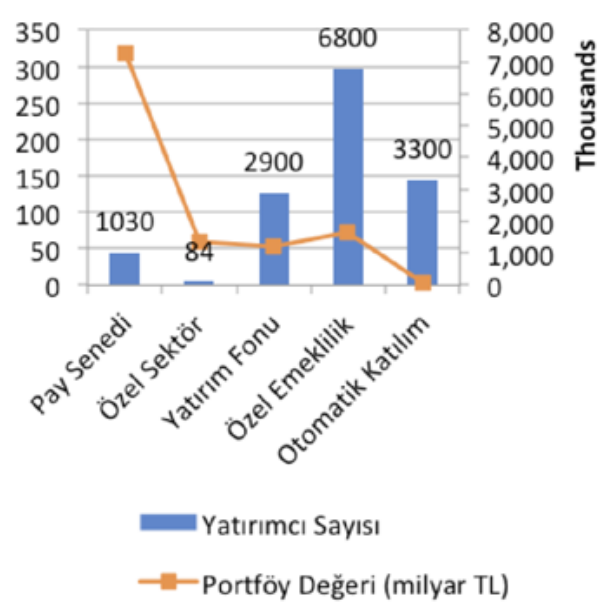

Grafik 2

Belirli Yatırım Araçlarına Göre Yatırımcı Sayısı ve Portföy Büyüklüğü (2017/9 itibariyle)

Kaynak: TSPB, Türkiye Sermaye Piyasaları, Aralık 2017, ss.59-67, https://www.tspb.org.tr/wp-content/uploads/2015/07/Turkish-Capital-Markets-2017-12-TR. pdf, (02.04.2018)

Türkiye Sermaye Piyasaları Birliği'nin 2011 yılında yaptığı "Sermaye Piyasas1 Alg1 ve Yatırım Potansiyeli Belirleme 
Araştırması"nda Türk sermaye piyasasında yatırım araçlarının bilinirliği, yatırım araçlarının kullanım alışkanlıkları, yatırım araçlarından memnuniyeti ölçülmüştür. Araştırmaya göre finansal yatırım deyince Türk sermaye piyasasında akla ilk gelen yatırım aracı sorusuna $\% 36$ oranında altın, \%22 oranında gayrimenkul, \%21 mevduat, \%12 döviz, $\% 4$ pay senedi cevabı verilmiştir. Yine rapora göre yatırım araçlarının bilinirliği açısından en çok tanınan yatırım aracı altın olup en az bilinen ise foreks işlemleridir. Raporda dikkat çeken önemli unsurlardan biri de yatırımcıların yatırım aracı seçerken dikkat ettiği kriterlerin başında getirinin yüksek olması, riskin düşük olması ve güvenilir olması gelmektedir. Risk ve getirinin doğru orantılı olduğu finansal piyasalarda yatırımcının yüksek getiri, düşük risk beklemesi rasyonel olabilir ancak risk olmadan yüksek getiri beklentisi ile yatırımcının sermaye piyasasında yatırım yapma konusunda çekindiği söylenebilir. Diğer yandan Türk yatırımcının belirli özellikleri şöyle sıralanabilir;

- Kısa vadeli yatırım araçlarını tercih etmektedir.

- Yatırım yapmayan kesim gelir yetersizliği sebebi ile yatırım yapamamaktadır.

- Yatırımcıyı koruma fonu gibi güvenlik önlemlerinin bilinirliği çok düşüktür.

- Altın ve mevduat güvenilir, gayrimenkul getirisi yüksek olarak nitelendirilmektedir.

- Yatırımcının tercih etmeyeceği yatırım araçlarının başında pay senedi, repo-ters repo gelmektedir.

\section{Araştırma Yöntemi ve Analiz}

Çalışmanın bu bölümünde verilerin yapısına uygun olarak belirlenen araştırma yöntemi ile test edilmek istenen hipotezlerin geliştirilmesi ve analizlerine yer verilmektedir. Çalışmada kuşak farklılıklarının yatırımcıların portföy değeri ile yatırımcı sayıları arasındaki ilişkinin nasıl olduğu ortaya konmak istenmekle birlikte yatırımcı uyruğu ve menkul kıymet türü gibi değişkenlerin etkisinin de ne olduğu ortaya konacaktır.

\section{Veri Seti ve Değişkenler}

Araştırmada kullanılan veri seti Merkezi Kayıt Kuruluşu'ndan talep edilmiştir. Elde ettiğimiz veriler yatırımcılara ait 2015-2016 yıllarını kapsayan yaş, menkul kıymet türü, yatırımcı uyruğu, portföy değeri ve yatırımc1 sayısı değerlerini içermektedir. Bu veriler üzerinden araştırma tasarımı gerçekleştirilmiştir.

Veri setinde yer alan yatırımcıların yaşları kullanılarak Z kuşağı için 2000 ve sonrası; Y kuşağ1 için 1980-1999; X kuşağ1 için 1965 - 1979; Baby boom olarak adlandırılan dönem için 1946-1979 ve son olarak Sessiz kuşak olarak tanımlanan grup için de 1927-1945 yılları baz alınmıştır. Kıymet türü değişkeni olarak MKK'nın tanımladığı Devlet İç Borçlanma Senetleri (DİBS), Fonlar, Pay senetleri, Özel sektör borçlanma araçları, Diğer menkul kıymetler ile yapılandırılmış ürünler kullanılmıştır. Yatırımcı uyruğu olarak da yerli ve yabancı sınıflaması yer almaktadır. Analizlerde özellikle bağımlı değişken olarak kullanılan portföy değerleri ile yatırımcı sayıları 2015 ve 2016 yılları için kullanıl- 
mıştır. İki yıllık analiz dönemi verilerin elde edilmesinden kaynaklandığ 1 için bu araştırmanın bir kısıtı olarak görülmelidir. Bağımlı değişkenler sürekli değişken yapısında olup diğer değişkenler kategorik bir yapıda analizlerde yer almaktadır.

\section{Araştırma Hipotezleri ve Kullanılan Testler}

Çalışmanın temel amacı kapsamında yedi adet hipotez test edilmek istenmektedir. Araştırma kapsamında test etmek istediğimiz hipotezler aşağıda görüldüğü gibidir. Bu hipotezlerden birincisi Ki kare testi; 2, 3, 4 ve 5 Kruskal Wallis testi ve 6 ve 7 ise Çift Yönlü ANOVA ile test edilmiştir. Bu çalışmada kullanılan Ki kare testi iki kategorik değişkenin birbiriyle olan ilişkisini ortaya koymak için uygulanmıştır. Kruskal Wallis testi ile bağımlı değişkenin normal dağılım göstermediği ve ikiden fazla olan grupların ortalama farklılıkları test edilmiştir. Bu testin parametrik olan çeşidi ise Tek Yönlü ANOVA analizidir. Dolayssiyla bu hipotezlerden 1 ile 5 arasında kalanlar parametrik olmayan testlerdir. Bunun temel sebebi ise bağımlı değişkenlerin özellikle örneklem yapısından ötürü normal dağılım göstermemelidir. Buna karşın, yine veri setinin yapısından kaynaklı olarak 6 ve 7 numaralı hipotezler parametrik bir test olan çift yönlü ANOVA analizi ile test edilmiştir. Bu analiz, bağımlı değişkenin normal dağılım gösterdiği durumlarda uygulanan bir analiz olmasına rağmen bu veri seti için iki değişkenin ve iki değişkenin etkileşiminin aynı anda ölçebilecek güçlü bir parametrik olmayan testin olmamasından kaynaklanmıştır. $\mathrm{Bu}$ durumun da bir analiz kısıtı olarak görülmesi yerinde olacaktır.

Tablo 1

Değişken ve tanımlamaları

\begin{tabular}{|c|c|c|c|}
\hline Değişken Adı & Değişken Türü & Değişken Tanımı & Kaynak \\
\hline Kuşak & Kategorik & $\begin{array}{l}\text { 1: Z kuşağı (2000 ve sonrası) } \\
\text { 2: Y kuşağı (1980-1999) } \\
\text { 3: X kuşağı (1965- 1979) } \\
\text { 4: Büyük Bebek Patlaması kuşağ1 } \\
\text { (1946-1965) } \\
\text { 5: Sessiz kuşağı (1927-1945) }\end{array}$ & Kuyucu, M. (2014). \\
\hline Kiymet Türü & Kategorik & $\begin{array}{l}\text { 1: Devlet İç Borçlanma Senetleri } \\
\text { 2: Fon } \\
\text { 3: Pay Senedi } \\
\text { 4: Özel Sektör Borçlanma Araçları } \\
\text { 5: Diğer Menkul Kiymetler } \\
\text { 6: Yapılandırılmış Ürünler }\end{array}$ & Merkezi Kayıt Kuruluşu \\
\hline Yatırımcı Uyruğu & Kategorik & $\begin{array}{l}\text { 1: Yerli } \\
\text { 2: Yabanc1 }\end{array}$ & Merkezi Kayıt Kuruluşu \\
\hline $\begin{array}{l}\text { Cari Dönem Portföy } \\
\text { Değeri (M TL) }\end{array}$ & Sürekli & 2016 Y11 & Merkezi Kayıt Kuruluşu \\
\hline $\begin{array}{l}\text { Geçen Dönem Portföy } \\
\text { Değeri (M TL) }\end{array}$ & Sürekli & $2015 Y_{11}$ & Merkezi Kayıt Kuruluşu \\
\hline $\begin{array}{l}\text { Cari Dönem Yatırımcı } \\
\text { Sayısı }\end{array}$ & Sürekli & $2016 Y_{1} l_{1}$ & Merkezi Kayıt Kuruluşu \\
\hline $\begin{array}{l}\text { Geçen Dönem Yatırımcı } \\
\text { Sayısı }\end{array}$ & Sürekli & $2015 Y_{1} l_{1}$ & Merkezi Kayıt Kuruluşu \\
\hline
\end{tabular}


H1: Kuşaklar arasında (riskli) yatırım tercihlerinde fark yoktur

H2: Kuşaklar arasında yatırımcı sayısı bakımından fark yoktur

H3: Kuşaklar arasında yatırımcıların portföy değerleri bakımından fark yoktur

H4: Menkul kıymet sinıflart arasında portföy değeri bakımından fark yoktur

H5: Menkul kiymet sinıfları arasında yatırımcı sayısı bakımından fark yoktur

H6: Kuşaklar arasında menkul kuymet sinıfları kontrol edildiğinde portföy değeri bakımından fark yoktur

H7: Kuşaklar arasında menkul kıymet sinıflart kontrol edildiğinde yattrimcı sayısı bakımindan fark yoktur

\section{Analiz Sonuçları}

\section{Tanımlayıcı İstatistikler}

Veri setinin yapısı gereği yaş kategorileri üzerinden bağımlı değişken olarak kullanılan portföy değerleri ile yatırımcı sayıları sınırlı sayida hipotezin test edilmesine olanak vermiştir. Bu veri seti yapısında söz gelimi 0-14 yaş grubuna düşen portföy değeri ile yatırımc1 sayıs1 istatistikleri verilmektedir. Bu k1sit kapsamında Tablo 2 incelendiğinde $\mathrm{Z}$ kuşağındaki gözlem (grup) sayısının 20 olduğu görülmektedir. $\mathrm{Bu} 20$ gruptan kast edilen 0-14 ile 15-19 yaș gruplarına düșen gözlemlerdir (gruplardır). Elbette her grup kendi içlerinde de kıymet türü ve yatırımcı uyruğu olarak da ayrılmaktadır. Buna göre, kuşak dağılımları bakımında portföy değerleri ile yatırımc1 sayıları incelendiğinde hem portföy değeri hem de yatırımcı sayıları itibariyle en düşük grubun $\mathrm{Z}$ kuşağı olduğu görülmektedir. $\mathrm{Bu}$ durum yatırımcıların genç ve servet birikimlerinin düşük olmasından ötürü tutarlı bir sonuç olarak ortaya çıkmaktadır. Bunun yanında kısaca BEBEK (Büyük bebek patlaması) olarak ifade ettiğimiz kuşak ise portföy değeri itibariyle en yüksek yatırıma sahiptir. En fazla yatırımcıya sahip olan kuşak ise $X$ kuşağıdır.

Kuşak ve kıymet türleri bağlamında veri seti düzenlemesi Tablo da yer almaktadır. Burada her kuşağa karşllık gelen portföy değeri ile yatırımcı sayıları görülmektedir. Buna göre, $Z$ kuşağınında fon yatırımlarında en yüksek portföy değeri gözlenirken, Y, X, BEBEK ve SESSIZ kuşaklarında pay senedi yatırımlarının en yüksek değere sahip olduğu gözlenmiş̧ir. Bu istatistiklere ilişkin detaylı açıklamalar hipotez testleri ile beraber verilecektir.

\section{Hipotez Testlerinin Sonuçları}

Çalışmanın bu aşamasında geliştirilen hipotezlere ilişkin testler yer almaktadır. Bu testlere geçmeden analizlerde bağımlı değişken olarak kullanılan portföy değerleri ile yatırımcı sayılarına ilişkin temel istatistikler Tablo 4'te verilmektedir. Bu istatistiklerden basıklık ve çarpıklık değerlerinin +1 ile -1 arasında kalmadıkları dolayısıyla da normal dağılmadıkları (Gürbüz ve Şahin, 2014:210) görülmektedir. Bu değişkenlerin normal dağılmamasından ötürü parametrik olmayan testlerin kullanılması uygun görülmüş̧ür. Sadece 6 ve 7 numaralı hipotezler bu varsayımı dikkate almadan parametrik bir test olan çift yönlü ANOVA analizi ile test edilmiştir. 
Tablo 2

Kuşaklara göre portföy değerleri ve yatırımcı sayıları

\begin{tabular}{|c|c|c|c|c|c|}
\hline & Gözlem & $\begin{array}{c}\text { Cari Dönem Portföy } \\
\text { Değeri } \\
\text { (M TL) } 2016 \\
\end{array}$ & $\begin{array}{c}\text { Geçen Dönem Port- } \\
\text { föy Değeri } \\
\text { (M TL) } 2015 \\
\end{array}$ & $\begin{array}{c}\text { Cari Dönem } \\
\text { Yatırımcı Sayısı } \\
2016 \\
\end{array}$ & $\begin{array}{c}\text { Geçen Dönem Yatı- } \\
\text { rımcı Sayısı } \\
2015 \\
\end{array}$ \\
\hline Kuşak & (grup)* & Ortalama & Ortalama & Ortalama & Ortalama \\
\hline $\mathrm{Z}$ & 20 & 41,10 & 40,85 & 11510,50 & 11505,85 \\
\hline Y & 48 & 344,31 & 335,40 & 21329,65 & 20966,98 \\
\hline $\mathrm{X}$ & 39 & 1325,95 & 1293,54 & 37916,67 & 37700,51 \\
\hline BEBEK & 31 & 1376,13 & 1347,55 & 33325,13 & 33197,29 \\
\hline SESSIZZ & 21 & 1180,29 & 1161,71 & 17275,62 & 17204,52 \\
\hline Toplam & 159 & 858,53 & 839,84 & 25966,35 & 25768,95 \\
\hline
\end{tabular}

Tablo 3

Kuşak ve kıymet türlerine göre portföy değerleri ve yatırımcı sayıları

\begin{tabular}{|c|c|c|c|c|c|c|}
\hline \multirow[t]{2}{*}{ Kuşak } & \multirow[t]{2}{*}{ Kıymet Sınıfi } & \multirow[t]{2}{*}{ Gözlem } & $\begin{array}{c}\text { Cari Dönem } \\
\text { Portföy Değeri } \\
\text { (M TL) } 2016\end{array}$ & $\begin{array}{l}\text { Geçen Dönem } \\
\text { Portföy Değeri } \\
\text { (M TL) } 2015\end{array}$ & $\begin{array}{c}\text { Cari Dönem } \\
\text { Yatırımcı Sayısı } \\
2016 \\
\end{array}$ & $\begin{array}{c}\text { Geçen Dönem } \\
\text { Yatırımcı Sayısı } \\
2015 \\
\end{array}$ \\
\hline & & & Ortalama & Ortalama & Ortalama & Ortalama \\
\hline \multirow{6}{*}{ Z } & $\begin{array}{l}\text { Devlet iç borç- } \\
\text { lanma senetleri }\end{array}$ & 4 & 2,00 & 2,00 & 60,75 & 57,25 \\
\hline & Fon & 4 & 128,75 & 127,75 & 56689,75 & 56691,75 \\
\hline & Pay senedi & 4 & 58,25 & 59,00 & 709,50 & 673,00 \\
\hline & $\begin{array}{l}\text { Özel sektör } \\
\text { borçlanma } \\
\text { araçları }\end{array}$ & 4 & 6,75 & 6,00 & 85,00 & 100,25 \\
\hline & $\begin{array}{l}\text { Diğer menkul } \\
\text { kiymetler }\end{array}$ & 2 & 19,50 & 19,00 & 6,00 & 6,00 \\
\hline & $\begin{array}{l}\text { Yapılandırılmış } \\
\text { ürünler }\end{array}$ & 2 &, 00 &, 00 & 9,00 & 8,00 \\
\hline \multirow{6}{*}{$\mathrm{Y}$} & $\begin{array}{l}\text { Devlet iç borç- } \\
\text { lanma senetleri }\end{array}$ & 8 & 28,13 & 28,37 & 1434,63 & 1459,87 \\
\hline & Fon & 8 & 729,38 & 717,50 & 91766,13 & 90851,88 \\
\hline & Pay senedi & 8 & 1077,38 & 1040,38 & 32993,63 & 31587,62 \\
\hline & $\begin{array}{l}\text { Özel sektör } \\
\text { borçlanma } \\
\text { araçları }\end{array}$ & 8 & 203,25 & 199,62 & 1215,13 & 1347,00 \\
\hline & $\begin{array}{l}\text { Diğer menkul } \\
\text { kiymetler }\end{array}$ & 8 & 26,38 & 24,63 & 215,50 & 209,25 \\
\hline & $\begin{array}{l}\text { Yapılandırılmış } \\
\text { ürünler }\end{array}$ & 8 & 1,38 & 1,88 & 352,88 & 346,25 \\
\hline \multirow{6}{*}{$\mathrm{X}$} & $\begin{array}{l}\text { Devlet iç borç- } \\
\text { lanma senetleri }\end{array}$ & 6 & 79,83 & 75,50 & 2123,17 & 2100,33 \\
\hline & Fon & 6 & 2739,17 & 2701,17 & 164430,00 & 163461,00 \\
\hline & Pay senedi & 6 & 4834,33 & 4725,00 & 75304,00 & 74468,17 \\
\hline & $\begin{array}{l}\text { Özel sektör } \\
\text { borçlanma } \\
\text { araçları }\end{array}$ & 6 & 872,67 & 827,50 & 3834,33 & 4277,00 \\
\hline & $\begin{array}{l}\text { Diğger menkul } \\
\text { kıymetler }\end{array}$ & 6 & 89,83 & 75,83 & 378,83 & 364,33 \\
\hline & $\begin{array}{l}\text { Yapılandırılmış } \\
\text { ürünler }\end{array}$ & 9 & 1,89 & 2,00 & 258,67 & 255,00 \\
\hline
\end{tabular}


Tablo 3

Kuşak ve kıymet türlerine göre portföy değerleri ve yatırımcı saylarl

\begin{tabular}{|c|c|c|c|c|c|c|}
\hline \multirow[t]{2}{*}{ Kuşak } & \multirow[t]{2}{*}{ Kıymet Sınıfı } & \multirow[t]{2}{*}{ Gözlem } & $\begin{array}{c}\text { Cari Dönem } \\
\text { Portföy Değeri } \\
\text { (M TL) } 2016\end{array}$ & $\begin{array}{l}\text { Geçen Dönem } \\
\text { Portföy Değeri } \\
\text { (M TL) } 2015\end{array}$ & $\begin{array}{c}\text { Cari Dönem } \\
\text { Yatırımcı Sayısı } \\
2016\end{array}$ & $\begin{array}{c}\text { Geçen Dönem } \\
\text { Yatırımcı Sayısı } \\
2015\end{array}$ \\
\hline & & & Ortalama & Ortalama & Ortalama & Ortalama \\
\hline \multirow{6}{*}{ BEBEK } & $\begin{array}{l}\text { Devlet iç borç- } \\
\text { lanma senetleri }\end{array}$ & 6 & 84,17 & 81,50 & 1556,50 & 1520,17 \\
\hline & Fon & 6 & 2277,83 & 2276,33 & 118300,67 & 117341,17 \\
\hline & Pay senedi & 6 & 3459,33 & 3365,67 & 47611,83 & 47464,83 \\
\hline & $\begin{array}{l}\text { Özel sektör } \\
\text { borçlanma } \\
\text { araçları }\end{array}$ & 6 & 1194,83 & 1143,67 & 4535,17 & 5025,33 \\
\hline & $\begin{array}{l}\text { Diğger menkul } \\
\text { kiymetler }\end{array}$ & 6 & 93,83 & 95,17 & 172,50 & 164,50 \\
\hline & $\begin{array}{l}\text { Yapılandırılmış } \\
\text { ürünler }\end{array}$ & 1 &, 00 &, 00 & 19,00 & 20,00 \\
\hline \multirow{6}{*}{ SESSİZ } & $\begin{array}{l}\text { Devlet iç borç- } \\
\text { lanma senetleri }\end{array}$ & 4 & 78,75 & 76,25 & 743,50 & 718,00 \\
\hline & Fon & 4 & 2055,50 & 2036,75 & 62780,00 & 62104,25 \\
\hline & Pay senedi & 4 & 2848,25 & 2869,75 & 23975,00 & 24006,75 \\
\hline & $\begin{array}{l}\text { Özel sektör } \\
\text { borçlanma } \\
\text { araçları }\end{array}$ & 4 & 1192,75 & 1095,75 & 3142,75 & 3443,25 \\
\hline & $\begin{array}{l}\text { Diğer menkul } \\
\text { kiymetler }\end{array}$ & 4 & 21,25 & 20,50 & 50,50 & 47,00 \\
\hline & $\begin{array}{l}\text { Yapılandırılmış } \\
\text { ürünler }\end{array}$ & 1 &, 00 &, 00 & 21,00 & 18,00 \\
\hline
\end{tabular}

Birinci hipoteze ilişkin analiz Ki kare testi ile mümkün olmaktadır. Burada araştırılmak istenen kuşak yapısıyla menkul kıymet dağılımları arasında bir ilişkinin varlığıdır. Buradan kasıt risk düzeyleri farklı olan menkul kıymet türleri ile kuşak yapılarının ilişkisidir. Tablo 5'de söz konusu dağılım görülmektedir. Örneğin $Z$ kuşağı $Y$ kuşağına göre daha az sayıda gözleme (gruba) sahiptir. Ancak bu durum, Y kuşağının yaş aralığı ile ilgilidir. MKK'dan alınmış olan veri seti her bir yatırımcı yerine yaş aralığ üzerinden istatistik verdiği için burada yapılmak istenen test amaç bakımından doğru olsa da uygulama açısından eksiktir. Buna rağmen, ilgili hipotezin önemi ve test edilmesi gerekliliği 6 ve 7 numaralı hipotezlerde ayrıca bağımlı değişkenlerin de hesaba katılması sonucunda doğru bir şekilde test edilmiştir.

Birinci hipotezin testine geçmeden önce öncelikle Tablo 6'da yer alan kuşak ve gözlem grupları dağılımının Ki kare testi yapılmıştır. Buna göre kuşaklar arasında gözlem gruplarının dağılımı eşit değildir $(\mathrm{p}=, 001<0,05)$. Zira, $Z$ kuşağında 20 gözlem grubu yer alırken, Y kuşağında 48 gözlem grubu yer almaktadır. Burada tekrar ifade edilmesi gereken husus bu farklılığın MKK veri yayınlama yapısından ve kuşaklar arasındaki zaman farklılığından ileri geldiğidir. Dolayısıyla söz konusu farklılık iki kategorik değişken arasındaki durumu ortaya koymasına rağmen arzu edilen durumu test 
Tablo 4

Bağımlı değişkenlere ilişkin temel istatistikler

\begin{tabular}{|c|c|c|c|c|c|}
\hline & & $\begin{array}{l}\text { Cari Dönem Portföy } \\
\text { Değeri (M TL) } 2016\end{array}$ & $\begin{array}{c}\text { Geçen Dönem Port- } \\
\text { föy Değeri (M TL) } \\
2015\end{array}$ & $\begin{array}{l}\text { Cari Dönem Yatı- } \\
\text { rımcı Sayısı } \\
2016\end{array}$ & $\begin{array}{c}\text { Geçen Dönem Yatı- } \\
\text { rımcı Sayısı } \\
\mathbf{2 0 1 5}\end{array}$ \\
\hline \multirow{2}{*}{ Gözlem } & Geçerli & 159 & 159 & 159 & 159 \\
\hline & Geçersiz & 0 & 0 & 0 & 0 \\
\hline Ortalama & & 858,5346 & 839,8365 & 25966,3522 & 25768,9497 \\
\hline Std. Sapma & & 2014,21590 & 1977,75828 & 68005,43834 & 67455,43305 \\
\hline Basıklık & & 2,946 & 2,951 & 3,096 & 3,106 \\
\hline Çarpıklık & & 9,318 & 9,286 & 9,375 & 9,448 \\
\hline Minimum & &, 00 &, 00 & 1,00 & 1,00 \\
\hline Maksimum & & 12072,00 & 11781,00 & 334100,00 & 331763,00 \\
\hline
\end{tabular}

H1: Kuşaklar arasında (riskli) yatırım tercihlerinde fark yoktur

edememektedir. Bu durum, 6 ve 7 numaralı hipotez testlerinde doğru bir şekilde gösterilmiştir. Birinci hipotezin formal testi ise Tablo 7'de verilmektedir. Buna göre, kuşak yapısı ile menkul kıymet dağılımı arasında istatistiksel olarak anlamlı bir ilişki bulunamamıştır ( $p=, 985>0,05)$. Başka bir ifade ile kuşaklar arasındaki menkul kıymet dağılımı istatistiksel olarak anlamsızdır.

Kuşaklar arasında portföy değerleri ile yatırımcı sayıları bakımlarından farklılık olup olmadığı 2 ve 3 numaralı hipotezlerle test edilmektedir. Tablo 8'den de görüleceğe üzere porföy değeri itibariyle $Z$ ve Y kuşaklarının ortalaması diğer kuşakların çok gerisindedir. Buna karşın X, BEBEK ve SESSIZZ kuşaklar portföy değeri itibariyle birbirlerine yakındırlar. Tablo 9'da yer alan ve Kruskal Wallis testi ile de sabit olan durum bu kuşaklar arasında portföy değer ortalamaları hem 2015 hem de 2016 yılları için farklıdır $(\mathrm{p}=, 000<0,05)$. Bu aşamada hangi kuşakların birbirlerinden farklı olduğuna ilişkin ileri testlerin sonuçlarını çalışmanın uzunluk kısıtı sebebiyle burada yer verilmemiştir. Ancak, Tablo 8'de görüleceği üzere, $Z$ ve $Y$ kuşakları ile $X, B E-$
BEK ve SESSIZ kuşaklar kendi aralarında görece yakındırlar.

Aynı durumun yatırımc1 sayıları itibariyle değerlendirilmesinde $\mathrm{Z}$ kuşağının özellikle diğer kuşaklardan daha az sayıda yatırımcı barındırdığı görülmektedir. Bununla beraber, $X$ kuşağının hem 2015 hem de 2016 yılları için en çok yatırımcı barındırdığ 1 Tablo 8'de görülmektedir. Yatırımc1 sayısının kuşaklar arasındaki dağılımın istatistiksel olarak farklı olduğunu Tablo 9'da yer alan Kruskal Wallis testi ile ortaya konmuştur $(p=, 031<0,05)$. Bu sonuçta en etkili durumun $\mathrm{Z}$ kuşağındaki görece daha az sayıda yatırımcinın olmasıdır. Bununla beraber, $X$ ve BEBEK kuşaklarındaki yatırımcı sayıları ile Y ve SESSIZZ kuşaktaki yatırımcı sayıları görece birbirine yakındır.

Araştırma kapsamında test edilmek istenen bir husus olan menkul kiymet sinıfları arasında portföy değeri ve yatırımcı sayılarının farklılığı durumları hipotez 4 ve 5 ile gerçekleştirilmektedir. Tablo 10 'da verilen kıymet sınıfları arasındaki portföy değeri ile yatırımcı sayılarının ortalamaları bakımından değerlendirildiğinde pay senetleri ile fonların 
Tablo 5

Kuşak ve kıymet sınıfi dă̆ılımı

\begin{tabular}{|c|c|c|c|c|c|c|c|}
\hline \multirow[b]{3}{*}{ Kuşak } & \multicolumn{7}{|c|}{ Kıymet Sinıfi } \\
\hline & $\begin{array}{c}\text { devlet iç } \\
\text { borçlanma senetleri }\end{array}$ & fon & $\begin{array}{c}\text { pay } \\
\text { senedi }\end{array}$ & $\begin{array}{c}\text { özel sektör } \\
\text { borçlanma } \\
\text { araçları }\end{array}$ & $\begin{array}{c}\text { diğer menkul } \\
\text { kıymetler }\end{array}$ & $\begin{array}{l}\text { yapılandırıl- } \\
\text { mış ürünler }\end{array}$ & Toplam \\
\hline & Göz. & Göz. & Göz. & Göz. & Göz. & Göz. & Göz. \\
\hline $\mathrm{Z}$ & 4 & 4 & 4 & 4 & 2 & 2 & 20 \\
\hline $\mathrm{Y}$ & 8 & 8 & 8 & 8 & 8 & 8 & 48 \\
\hline $\mathrm{X}$ & 6 & 6 & 6 & 6 & 6 & 9 & 39 \\
\hline BEBEK & 6 & 6 & 6 & 6 & 6 & 1 & 31 \\
\hline SESSİZ & 4 & 4 & 4 & 4 & 4 & 1 & 21 \\
\hline Toplam & 28 & 28 & 28 & 28 & 26 & 21 & 159 \\
\hline
\end{tabular}

Tablo 6

Kuşak ve gözlem grupları dağılımı Ki kare testi

\begin{tabular}{|c|c|c|c|c|c|}
\hline & Gözlenen N & Beklenen N & $\chi^{2}$ & Ser.Der. & $\mathbf{P}$ \\
\hline Z & 20 & 31,8 & & & \\
\hline Y & 48 & 31,8 & & & \\
\hline $\mathrm{X}$ & 39 & 31,8 & 17,950 & 4 & ,001 \\
\hline BEBEK & 31 & 31,8 & & & \\
\hline SESSİZ & 21 & 31,8 & & & \\
\hline Toplam & 159 & & & & \\
\hline
\end{tabular}

portföy değerleri diğer menkul kıymetlere göre daha yüksektir. Yatırımcı sayısı bakımında ise fon yatırımlarının uzak ara yüksek yatırımc1 çektiği görülmektedir. Bu durum, yatırım fonlarının sağladığı, düşük işlem maliyeti, çeşitlendirme firsatı ve bilgi asimetrisinin azalımı özellikleriyle açıklanabilir.
Tablo 11'de verilen kıymet sınıfları arasında portföy değeri ve yatırımcı sayısı dağılımı Kruskal Wallis testi sonuçlarına göre ise hem portföy değerleri $(p=, 000<0,05)$ hem de yat1rımcı sayıları $(\mathrm{p}=, 000<0,05)$ menkul kıymet türleri arasında farklılık göstermektedir. Bununla beraber, fon ve pay senetleri hem port-

Tablo 7

Kuşak ve kıymet sınıfi dağılımı Ki kare testi

\begin{tabular}{|c|c|c|c|c|c|c|c|c|c|c|c|}
\hline \multirow[b]{2}{*}{ Kuşak } & & \multicolumn{7}{|c|}{ Kıymet Sınıfi Kukla } & \multirow[b]{2}{*}{$\chi^{2}$} & \multirow[b]{2}{*}{$\begin{array}{l}\text { Ser. } \\
\text { Der. }\end{array}$} & \multirow[b]{2}{*}{$\mathbf{P}$} \\
\hline & & $\begin{array}{c}\text { Devlet iç } \\
\text { borçlanma } \\
\text { senetleri }\end{array}$ & Fon & $\begin{array}{c}\text { Pay } \\
\text { senedi }\end{array}$ & $\begin{array}{c}\text { Özel sektör } \\
\text { borçlanma } \\
\text { araçları }\end{array}$ & $\begin{array}{c}\text { Diğer } \\
\text { menkul } \\
\text { kıymetler }\end{array}$ & $\begin{array}{l}\text { Yapılan- } \\
\text { dırılmış } \\
\text { ürünler }\end{array}$ & Toplam & & & \\
\hline \multirow{2}{*}{ Z } & Gözlenen & 4 & 4 & 4 & 4 & 2 & 2 & 20 & \multirow{10}{*}{8,831} & \multirow{10}{*}{20} & \multirow{10}{*}{,985 } \\
\hline & Beklenen & 3,5 & 3,5 & 3,5 & 3,5 & 3,3 & 2,6 & 20,0 & & & \\
\hline \multirow{2}{*}{ Y } & Gözlenen & 8 & 8 & 8 & 8 & 8 & 8 & 48 & & & \\
\hline & Beklenen & 8,5 & 8,5 & 8,5 & 8,5 & 7,8 & 6,3 & 48,0 & & & \\
\hline \multirow{2}{*}{$X$} & Gözlenen & 6 & 6 & 6 & 6 & 6 & 9 & 39 & & & \\
\hline & Beklenen & 6,9 & 6,9 & 6,9 & 6,9 & 6,4 & 5,2 & 39,0 & & & \\
\hline \multirow{2}{*}{ BEBEK } & Gözlenen & 6 & 6 & 6 & 6 & 6 & 1 & 31 & & & \\
\hline & Beklenen & 5,5 & 5,5 & 5,5 & 5,5 & 5,1 & 4,1 & 31,0 & & & \\
\hline \multirow{2}{*}{ SESSİZ } & Gözlenen & 4 & 4 & 4 & 4 & 4 & 1 & 21 & & & \\
\hline & Beklenen & 3,7 & 3,7 & 3,7 & 3,7 & 3,4 & 2,8 & 21,0 & & & \\
\hline \multirow{2}{*}{ Total } & Gözlenen & 28 & 28 & 28 & 28 & 26 & 21 & 159 & & & \\
\hline & Beklenen & 28,0 & 28,0 & 28,0 & 28,0 & 26,0 & 21,0 & 159,0 & & & \\
\hline
\end{tabular}


Tablo 8

Kuşaklar arasında protföy değeri ve yatırımcı sayısı dă̆ılımı

\begin{tabular}{lcccc}
\hline & Cari Dönem Portföy & $\begin{array}{c}\text { Geçen Dönem } \\
\text { Pertföy Değeri (M TL) } \\
\text { Kuşak }\end{array}$ & $\begin{array}{c}\text { Cari Dönem } \\
\text { Yatırımcı Sayısı }\end{array}$ & $\begin{array}{c}\text { Geçen Dönem } \\
\text { Yatırımcı Sayısı } \\
\mathbf{2 0 1 5}\end{array}$ \\
\hline Ortalama & Ortalama & Ortalama & Ortalama \\
Y & 41,10 & 40,85 & 11510,50 & 11505,85 \\
X & 344,31 & 335,40 & 21329,65 & 20966,98 \\
BEBEK & 1325,95 & 1293,54 & 37916,67 & 37700,51 \\
SESSIZ & 1376,13 & 1347,55 & 33325,13 & 33197,29 \\
\hline Toplam & 1180,29 & 1161,71 & 17275,62 & 17204,52 \\
\hline
\end{tabular}

föy değerleri hem de yatırımcı sayıları bakımından diğer menkul kıymetlere göre görece farklı gruplar oluşturmaktadırlar.

Araştırma kapsamında test edilmek istenen son iki hipotez ise menkul kıymet sınıfları kontrol değişkeni olarak kullanıldığında portföy değeri ve yatırımcı sayılarının kuşaklar arasında farklılık gösterip göstermemesidir. Bu amaçla, çift yönlü ANOVA analizi kullanılmıştır. Tablo 12'de kuşaklar

Tablo 9

Kuşaklar arasında protföy değeri ve yatırımcı sayısı dă̆llımı Kruskal Wallis testi

\begin{tabular}{|c|c|c|c|c|c|c|}
\hline & Kuşak & Gözlem & Ortalama Rank & $\chi^{2}$ & Ser.Der. & $\mathbf{P}$ \\
\hline \multirow{6}{*}{ Cari Dönem Portföy Değeri (M TL) } & $\mathrm{Z}$ & 20 & 47,18 & \multirow{6}{*}{22,812} & \multirow{6}{*}{4} & \multirow{6}{*}{, 000} \\
\hline & $\mathrm{Y}$ & 48 & 68,79 & & & \\
\hline & $\mathrm{X}$ & 39 & 85,44 & & & \\
\hline & BEBEK & 31 & 102,27 & & & \\
\hline & SESSİZ & 21 & 93,90 & & & \\
\hline & Toplam & 159 & & & & \\
\hline \multirow{6}{*}{ Geçen Dönem Portföy Değeri (M TL) } & $\mathrm{Z}$ & 20 & 46,90 & \multirow{6}{*}{22,774} & \multirow{6}{*}{4} & \multirow{6}{*}{, 000} \\
\hline & $\mathrm{Y}$ & 48 & 69,32 & & & \\
\hline & $\mathrm{X}$ & 39 & 84,68 & & & \\
\hline & BEBEK & 31 & 102,58 & & & \\
\hline & SESSIZ & 21 & 93,90 & & & \\
\hline & Toplam & 159 & & & & \\
\hline \multirow{6}{*}{ Cari Dönem Yatırımcı Sayısı } & $\mathrm{Z}$ & 20 & 52,10 & \multirow{6}{*}{10,650} & \multirow{6}{*}{4} & \multirow{6}{*}{, 031} \\
\hline & $\mathrm{Y}$ & 48 & 76,74 & & & \\
\hline & $\mathrm{X}$ & 39 & 87,19 & & & \\
\hline & BEBEK & 31 & 91,68 & & & \\
\hline & SESSİ & 21 & 83,43 & & & \\
\hline & Toplam & 159 & & & & \\
\hline \multirow{6}{*}{ Geçen Dönem Yatırımcı Sayısı } & $\mathrm{Z}$ & 20 & 52,15 & \multirow{6}{*}{10,646} & \multirow{6}{*}{4} & \multirow{6}{*}{, 031} \\
\hline & $\mathrm{Y}$ & 48 & 76,79 & & & \\
\hline & $\mathrm{X}$ & 39 & 87,14 & & & \\
\hline & BEBEK & 31 & 91,87 & & & \\
\hline & SESSİZ & 21 & 83,07 & & & \\
\hline & Toplam & 159 & & & & \\
\hline
\end{tabular}

H4: Menkul kıymet sınıfları arasında portföy değeri bakımından fark yoktur

H5: Menkul kıymet sınıfları arasında yatırımcı sayısı bakımından fark yoktur 
Tablo 10

Kıymet sınıfları arasında portföy değeri ve yatırımcı sayısı dă̆llımı

\begin{tabular}{lcccc}
\hline & $\begin{array}{c}\text { Cari Dönem } \\
\text { Portföy Değeri } \\
\text { (M TL) 2016 }\end{array}$ & $\begin{array}{c}\text { Geçen Dönem } \\
\text { Portföy Değeri } \\
\text { (M TL) 2015 }\end{array}$ & $\begin{array}{c}\text { Cari Dönem Yatı- } \\
\text { rımcı Sayısı } \\
\text { Kıymet Sınıfı }\end{array}$ & $\begin{array}{c}\text { Geçen Dönem } \\
\text { Yatırımcı Sayısı } \\
\mathbf{2 0 1 5}\end{array}$ \\
\hline Devlet iç borçlanma senetleri & 54,71 & 52,93 & Ortalama & Ortalama \\
Fon & 1595,50 & 1580,82 & 103871,14 & 1303,68 \\
Pay senedi & 2500,25 & 2449,36 & 39292,21 & 38679,21 \\
Özel sektör borçlanma araçları & 672,46 & 636,82 & 2601,75 & 2884,43 \\
Diğer menkul kıymetler & 55,27 & 51,65 & 201,77 & 194,12 \\
Yapılandırılmış ürünler & 1,33 & 1,57 & 248,05 & 243,76 \\
\hline
\end{tabular}

arasında kiymet sınıfı kontrol edildiğinde portföy değeri dağılımı Çift Yönlü ANOVA testi (Cari Dönem Portföy Değeri (M TL)) sonuçlarına 6. Hipotez için yer verilmiştir. $\mathrm{Bu}$ hipotez sonuçları benzer olmaları itibariyle sadece 2016 yılı için hesaplanmıştır. $\mathrm{Bu}$ sonuçlara göre, kuşaklar arasında portföy değerleri itibariyle farklılık olmaktadır $(p=, 013<0,05)$. Bu durum, bağımlı değişken olan portföy değeri ortalamasındaki oynaklığın \%9,3’ ünün kuşak farklılıklarından kaynaklandığını (kısmi eta kare $=0,093$ ) göstermektedir. Benzer şekilde, menkul kıymet türleri arasında portföy değerleri itibariyle farklılık olmaktadır $(\mathrm{p}=, 000<0,05) . \mathrm{Bu}$ durum ise portföy değeri ortalamasındaki oynaklığın \%23,2'sinin kıymet sınıfı farklılı̆̆ından kaynaklandığını gösterir. Ancak, kıymet sınıfı ile kuşak farklılığı etkileşimi istatistiksel olarak anlamlı etkiye sahip değildir $(p=, 404>0,05)$.

Benzer şekilde Tablo 13'te kuşaklar arasında kıymet sınıfı kontrol edildiğinde yatırımcı sayısı dağılımı Çift Yönlü ANOVA testi (Cari Dönem (2016) Yatırımc1 Sayısı) sonuçlarına 7. hipotez için yer verilmiştir. $\mathrm{Bu}$ hipotez sonuçları benzer olmaları itibariyle sadece 2016 yılı için hesaplanmıştır.
$\mathrm{Bu}$ sonuçlara göre, kıymet sınıfı kontrol edildiğinde kuşaklar arasında yatırımcı sayıları itibariyle farklılık olmamaktadır $(p=, 305>0,05) . B u$ durum, bağımlı değişken olan yatırımcı sayısı ortalamasındaki oynaklığın \%3,6'sının kuşak farklılıklarından kaynaklandığını (kısmi eta kare $=0,036)$ göstermektedir. Bu sonuç, Kruskal Wallis testi ile ortaya koyulan kuşaklar arasındaki yatırımcı sayısı farklılığına tezat oluşturmaktadır. Bu sonucun temel sebebi olarak Çift Yönlü ANOVA analizi varsayımlarından normal dağılımın bağımlı değişken için sağlanamamasına bağlanabilir. Buna karşın, menkul kıymet türleri arasında kuşak farklılığı kontrol edildiğine yatırımcı sayıları itibariyle farklılık olduğu görülmektedir $(p=, 000<0,05)$. Bu durum ise yatırımc1 sayısı ortalamasındaki oynaklığın \%30,4'ünün kıymet sınıfı farklılığından kaynaklandığını gösterir. Ancak, kıymet sınıfı ile kuşak farklılığ1 etkileşimi istatistiksel olarak anlamlı etkiye sahip değildir ( $p=, 534>0,05)$. Hem 6 . hem de 7. Hipotezler incelendiğinde Tablo 12 ve Tablo 13'te yer alan R kare değerleri (bağımlı değişkendeki oynaklığın bağımsız (faktör) değişkenleri ile açıklanma gücü) s1rasiyla $\% 39,5$ ve $\% 40,2$ olarak bulunmuştur. $\mathrm{Bu}$ oranlar, kuşak farklılığ 1 ile kıymet türü 
Tablo 11

Klymet sınıfları arasında protföy değgeri ve yatırımcı sayısı dă̆llımı Kruskal Wallis testi

\begin{tabular}{|c|c|c|c|c|c|c|}
\hline & Kıymet Sınıfı & Gözlem & Ortalama Rank & $\chi^{2}$ & Ser.Der. & $\mathbf{P}$ \\
\hline \multirow{7}{*}{$\begin{array}{l}\text { Cari Dönem } \\
\text { Portföy Değeri } \\
\text { (M TL) }\end{array}$} & Devlet iç borçlanma senetleri & 28 & 67,02 & \multirow{6}{*}{55,899} & \multirow{6}{*}{5} & \multirow{6}{*}{, 000} \\
\hline & Fon & 28 & 105,75 & & & \\
\hline & Pay senedi & 28 & 110,13 & & & \\
\hline & Özel sektör borçlanma araçları & 28 & 85,30 & & & \\
\hline & Diğer menkul kıymetler & 26 & 73,92 & & & \\
\hline & Yapılandırılmış ürünler & 21 & 23,26 & & & \\
\hline & Toplam & 159 & & & & \\
\hline \multirow{7}{*}{$\begin{array}{l}\text { Geçen Dönem } \\
\text { Portföy Değeri } \\
\text { (M TL) }\end{array}$} & Devlet iç borçlanma senetleri & 28 & 66,73 & \multirow{6}{*}{54,755} & \multirow{6}{*}{5} & \multirow{6}{*}{, 000} \\
\hline & Fon & 28 & 105,89 & & & \\
\hline & Pay senedi & 28 & 110,23 & & & \\
\hline & Özel sektör borçlanma araçları & 28 & 84,93 & & & \\
\hline & Diğer menkul kıymetler & 26 & 73,31 & & & \\
\hline & Yapılandırılmış ürünler & 21 & 24,57 & & & \\
\hline & Toplam & 159 & & & & \\
\hline \multirow{7}{*}{$\begin{array}{l}\text { Cari Dönem Yatı- } \\
\text { rımc1 Sayısı }\end{array}$} & Devlet iç borçlanma senetleri & 28 & 70,09 & \multirow{6}{*}{58,764} & \multirow{6}{*}{5} & \multirow{6}{*}{, 000} \\
\hline & Fon & 28 & 123,68 & & & \\
\hline & Pay senedi & 28 & 104,21 & & & \\
\hline & Özel sektör borçlanma araçları & 28 & 77,73 & & & \\
\hline & Diğer menkul kıymetler & 26 & 46,10 & & & \\
\hline & Yapılandırılmış ürünler & 21 & 47,69 & & & \\
\hline & Toplam & 159 & & & & \\
\hline \multirow{7}{*}{$\begin{array}{l}\text { Geçen Dönem } \\
\text { Yatırımcı Sayısı }\end{array}$} & Devlet iç borçlanma senetleri & 28 & 69,91 & \multirow{6}{*}{59,797} & \multirow{6}{*}{5} & \multirow{6}{*}{, 000} \\
\hline & Fon & 28 & 123,89 & & & \\
\hline & Pay senedi & 28 & 104,00 & & & \\
\hline & Özel sektör borçlanma araçları & 28 & 78,95 & & & \\
\hline & Diğer menkul kıymetler & 26 & 45,23 & & & \\
\hline & Yapılandırılmış ürünler & 21 & 47,38 & & & \\
\hline & Toplam & 159 & & & & \\
\hline
\end{tabular}

H6: Kuşaklar arasında menkul kıymet sınıfları kontrol edildiğinde portföy değeri bakımından fark yoktur

H7: Kuşaklar arasında menkul kıymet sınıfları kontrol edildiğinde yatırımcı sayısı bakımından fark yoktur

faktörlerinin hem portföy değeri hem de yatırımcı sayılarını önemli ölçüde açıkladığını göstermektedir.

\section{Sonuç}

Demografik ve sosyoekonomik değişkenler ile bireyin finansal risk toleransı arasında yakın bir ilişki olduğu varsayılmakta ve bu değişkenlere göre yatırımcıların risk profilleri çıkarılmaya çalışılmaktadır. Finansal risk toleransı ile demografik ve sosyoekonomik özellikler arasındaki ilişkiler açısından genel kabul gören görüşe göre yatırımcının yaşı arttıkça finansal risk toleransı azalmaktadır. Çalışmada Türk sermaye piyasasında Sessiz, Bebek, X, Y kuşaklarının finansal yatırım eğilimleri ve risk toleransları incelenmiştir. Kuşaklara göre yatırım araçlarının türlerine ne kadar yatırım yapıldığg ortaya konulan çalışmada böylelikle kuşakların finansal risk toleransı arasındaki farklılıklar incelenmiştir. 
Tablo 12

Kuşaklar arasında kıymet sınıfi kontrol edildiğinde portföy değeri dă̆ılımı Çift Yönlü ANOVA testi (Cari Dönem (2016) Portföy Değeri (MTL))

\begin{tabular}{lcccccc}
\hline & Tür III Kareler Toplamı & Ser.Der. & Ortalama kare & F & $p$ & Kismi Eta Kare \\
\hline Düzeltilmiş Model & $253329718,213^{a}$ & 29 & 8735507,525 & 2,907 &, 000 &, 395 \\
Sabit & 75329850,105 & 1 & 75329850,105 & 25,065 &, 000 &, 163 \\
Kuşak & 39686878,753 & 4 & 9921719,688 & 3,301 &, 013 &, 093 \\
Kiymet sınıfı & 117280597,906 & 5 & 23456119,581 & 7,805 &, 000 &, 232 \\
Kuşak * Kıymet sınıfı & 63450180,178 & 20 & 3172509,009 & 1,056 &, 404 &, 141 \\
Hata & 387686661,347 & 129 & 3005322,956 & & & \\
Toplam & 758212361,000 & 159 & & & & \\
Düzeltilmiş Toplam & 641016379,560 & 158 & & & & \\
\hline
\end{tabular}

a. $\mathrm{R}$ Kare $=$,395 (Düzeltilmiş R Kare $=, 259$ )

Türk sermaye piyasasında 2016 yılındaki veriler bazında kuşak dağılımları bakımından portföy değerleri ile yatırımcı sayıları incelendiğinde hem portföy değeri hem de yat1rımcı sayıları itibariyle en düşük grubun $\mathrm{Z}$ kuşağı olduğu görülmektedir. Bu durum yatırımcıların genç ve servet birikimlerinin düşük olmasından ötürü tutarlı bir sonuç olarak ortaya çıkmaktadır. Bunun yanında kısaca Bebek Kuşağı ise portföy değeri itibariyle en yüksek yatırıma sahiptir. En fazla yatırımcıya sahip olan kuşak ise $X$ kuşağıdır. Kuşak ve kıymet türleri açısından bakıldığında Z kuşağında fon yatırımlarında en yüksek portföy değeri gözlenirken, Y, X, BEBEK ve SESSIZZ kuşaklarında pay senedi yatırımlarının en yüksek değere sahip olduğu gözlenmiş̧ir.
Menkul kıymet sınıfları arasındaki portföy değeri ile yatırımcı sayılarının ortalamaları bakımından değerlendirildiğinde pay senetleri ile fonların portföy değerleri diğer menkul kıymetlere göre daha yüksektir. Yatırımcı sayısı bakımında ise fon yatırımlarının uzak ara yükssek yatırımcı çektiği görülmektedir. Bu durum, yatırım fonlarının sağladığı, düşük işlem maliyeti, çeşitlendirme firsatı ve bilgi asimetrisinin azalımı özellikleriyle açıklanabilir. Menkul kıymet sınıfları arasında portföy değeri ve yatırımcı sayısı dağılımı Kruskal Wallis testi sonuçlarına göre hem portföy değerleri hem de yatırımcı sayıları menkul kıymet türleri arasında farklılık göstermektedir. Bununla beraber, fon ve pay senetleri hem portföy değerleri hem de yatırımcı sayıları bakımından diğer menkul kıymetlere göre görece farklı gruplar oluşturmaktadırlar.

Tablo 13

Kuşaklar arasında kıymet sınıfı kontrol edildiğinde yatırımcı sayısı dă̆ılımı Çift Yönlü ANOVA testi (Cari Dönem Yatırımcl Sayısı)

\begin{tabular}{lcccccc}
\hline & Tür III Kareler Top- & & & & \\
& \multicolumn{1}{c}{ lamı } & Ser.Der. & Ortalama kare & F & Kismi Eta Kare \\
\hline Düzeltilmiş Model & $293937641665,652^{\text {a }}$ & 29 & 10135780747,091 & 2,994 &, 000 &, 402 \\
Sabit & 62063062188,496 & 1 & 62063062188,496 & 18,330 &, 000 &, 124 \\
Kuşak & 16537105613,675 & 4 & 4134276403,419 & 1,221 &, 305 &, 036 \\
Kıymet sınıfı & 191089275773,141 & 5 & 38217855154,628 & 11,288 &, 000 &, 304 \\
Kuşak * Kıymet sınıfı & 36137562482,245 & 20 & 1806878124,112 &, 534 &, 947 &, 076 \\
Hata & 436771222106,625 & 129 & 3385823427,183 & & & \\
Toplam & 837914843788,000 & 159 & & & & \\
Düzeltilmiş Toplam & 730708863772,277 & 158 & & & & \\
\hline
\end{tabular}

a. R Kare $=, 402$ (Düzeltilmiş R Kare $=, 268$ ) 
Menkul kıymet türleri arasında kuşak farkl1lığ 1 kontrol edildiğine yatırımc1 sayıları itibariyle farklılık olduğu görülmektedir. Bu durum ise yatırımcı sayısı ortalamasındaki oynaklığın \%30,4'ünün kıymet sınıfı farklılığından kaynaklandığını gösterir. Ancak, kıymet sınıfı ile kuşak farklılığ etkileşimi istatistiksel olarak anlamlı etkiye sahip değildir. kuşak farklılığ 1 ile kıymet türü faktörlerinin hem portföy değeri hem de yatırımcı sayılarını önemli ölçüde açıkladığını göstermektedir.

Analiz sonuçları kapsamında geliştirilen yedi adet hipotez Ki kare testi, Kruskal Wallis testi, çift yönlü ANOVA yöntemine göre test edilmiştir. Yapılan analizlerin sonucuna göre ulaşılan bulgular şu şekildedir:

- Kuşaklar arasında yatırımcı sayıları ve portföy değerleri farklılaşmaktadır.

- Kiymet türleri arasında yatırımcı sayılar1 ve portföy değerleri farklılaşmaktadır.

- Kuşaklar arasındaki menkul kıymet dağılımı istatistiksel olarak anlamsızdır.

- Kuşak ve kıymet türü değişkenleri yatırımcıların portföy değerleri ve sayılarını açıklamada önemli faktörlerdir.

Yapılan analizler ile yatırımcıların yaş faktörlerinden kaynaklanan kuşaklar arasindaki farklılıkların Türk sermaye piyasasinda da mevcut olduğu ortaya konulmuştur. İleride yapılacak başka çalışmalarda kuşaklar arasındaki cinsiyet, eğitim ve gelir seviyesi gibi farklılıklar da incelenerek çalışmanın sonuçları ile kıyaslanabilir.

\section{Kaynakça}

Alpay, E. E., Yavuz, M., \& Kahyaoğlu, M. (2015). Gelir Durumunun Risk Algısına Etki Eden Diğer Sosyo-Ekonomik Ve Demografik Faktörler Üzerindeki Etkisi. C.Ü. İktisadi ve İdari Bilimler Dergisi, Cilt 16, Say1 1.

Ameriks, J., Zeldes, S.P., 2004, September. How do household portfolio shares vary with age? Working paper. Columbia University Business School.

Anbar, A., \& Eker, M. (2012). Bireysel yatırımcıların finansal risk algılamalarını etkileyen demografik ve sosyoekonomik faktörler. Uluslararası Yönetim İktisat ve İsletme Dergisi, 5(9), 129-150.

Ayhün, S.E., 2013, Kuşaklar Arasındaki Farklılıklar ve Örgütsel Yansımaları, Ekonomi ve Yönetim Araştırmalar Dergisi, 2(1), 93-112.

Bakshi, G. S., \& Chen, Z. (1994). Baby boom, population aging, and capital markets. Journal of Business, 165-202.

Bali, Turan G. and Demirtas, K. Ozgur and Levy, Haim and Wolf, Avner, Bonds Versus Stocks: Investors' Age and Risk Taking. Journal of Monetary Economics, Vol. 56, No. 6, ss. 817-830, September 2009.

Bossons, J. (1973). The distribution of assets among individuals of different age and wealth. In R. W. Goldsmith (Ed.) Institutional Investors and Corporate Stock - A Background Study, 394-428.

Brooks, C., Sangiorgi, I., Hillenbrand, C., \& Money, K. (2018). Why are older investors less willing to take financial risks?. International Review of Financial Analysis.

Çiftçi, C. Jenerasyon Y`nin Yatırım Aracı Tercihleri: Oyun Teorisi Yaklaşımı. Karabük Üniversitesi Sosyal Bilimler Enstitüsü Dergisi, 7(2), 698-712.

Davydov, D., Florestedt, O., Peltomäki, J., \& Schön, M. (2017). Portfolio performance across genders and generations: The role of financial innovation. International Review of Financial Analysis, 50, 44-51.

Grable, J. E. (2000). Financial risk tolerance and additional factors that affect risk taking in everyday money matters. Journal of Business and Psychology, 14(4), 625-630. 
Grable J.E. (2008) Risk Tolerance. In: Xiao J.J. (eds) Handbook of Consumer Finance Research. Springer, New York, NY.

Grable, J. E. (1997). Investor risk tolerance: Testing the efficacy of demographics as differentiating and classifying factors(Doctoral dissertation, Virginia Tech).

Gürbüz, S. ve Şahin, F. (2015), Sosyal Bilimlerde Araştırma Yöntemleri 2. Basım. Ankara: Seçkin Yayıncılık.

Hallahan, T., Faff, R., \& McKenzie, M. (2003). An exploratory investigation of the relation between risk tolerance scores and demographic characteristics. Journal of Multinational Financial Management, 13(4-5), 483-502.

Hawley, C. B., \& Fujii, E. T. (1993-1994). An empirical analysis of preferences for financial risk: Further evidence on the Friedman-Savage model. Journal of Post Keynesian Economics, 16, 197-204.

Jagannathan R. ; Kocherlakota N.R. (1996). Why Should Older People Invest Less in Stocks Than Younger People?. Federal Reserve Bank Of Minneapolis Quarterly Review. Vol 20, no. 3

Kesbiç, C. Y., \& Yiğit, M. (2016). Bireysel Yatırım Tercihlerinde Risk Faktörünün Önemi; Manisa Ili Yatırımcı Profili Analizi. Finans Politik \& Ekonomik Yorumlar, 53(613), 79.

McInish, T. H. (1982). Individual investors and risk-taking. Journal of economic psycho$\log , 2$ (2), 125-136.

Kuyucu, M. (2014). Y Kuşağı Ve Facebook: Y Kuşağinin Facebook Kullanim Alişkanliklari Üzerine Bir İnceleme. Elektronik Sosyal Bilimler Dergisi, 49(49).

Morin, R. A., \& Suarez, A. F. (1983). Risk aversion revisited. The Journal of Finance, 38(4), 1201-1216.

Okun, M. A., \& Di Vesta, F. J. (1976). Cautiousness in adulthood as a function of age and instructions. Journal of Gerontology, 31(5), 571-576.

Roszkowski, M. J., Snelbecker, G. E., \& Leimberg, S. R. (1993). Risk tolerance and risk aversion. The tools and techniques of financial planning, 4(1), 213-225.

Sachse, K., Jungermann, H., \& Belting, J. M. (2012). Investment risk-The perspective of individual investors. Journal of Economic Psychology, 33(3), 437-447.
Saraç, M., \& Kahyaoğlu, M. B. (2011). Bireysel Yatırımcıların Risk Alma Eğilimine Etki Eden SosyoEkonomik ve Demografik Faktörlerin Analizi. Journal of BRSA Banking \& Financial Markets, 5(2).

Sulaiman, E. K. (2012). An empirical analysis of financial risk tolerance and demographic features of individual investors. Procedia Economics and Finance, 2, 109-115.

Tanyolac, C., \& Karan, M. B. (2015). Analyzıng Demographic Characteristics Of The Security Investors: An Application To Turkey. Journal of Economics Finance and Accounting, 2(4).

TSPB, Türkiye Sermaye Piyasaları, Aralık 2017, ss.56-57, https://www.tspb.org.tr/wp-content/ uploads/2015/07/Turkish-Capital-Markets2017-12-TR.pdf, (02.04.2018)

TSPB, "Sermaye Piyasas1 Alg1 ve Yatırım Potansiyeli Belirleme Araştırması", 2011, https:// www.tspb.org.tr/wpcontent/uploads/2015/06/ ETM_baskanin_konusmalari_SP_algi_anketi_basin_sunumu_13042011.pdf, (02.04.2018)

Usul, H., Bekçi, İ., \& Eroğlu, A. H. (2002). Bireysel Yatırımcıların Hisse Senedi Edinimine Etki Eden Sosyo-Ekonomik Etkenler. Erciyes Üniversitesi İktisadi ve İdari Bilimler Fakültesi Dergisi, (19), 135-150.

Vroom, V. H., \& Pahl, B. (1971). Relationship between age and risk taking among managers. $\mathrm{Jo}_{O}$ urnal of applied psychology, 55(5), 399.

Yao, R., Sharpe, D. L., \& Wang, F. (2011). Decomposing the age effect on risk tolerance. The Journal of Socio-Economics, 40(6), 879-887.

Yeşildağ E. , Atasever M., Kuduz N., Coşkun A. (2017) Afyonkarahisar ve Kütahya İllerindeki Hisse Senedi Yatırımcılarının Profili ve Yatırım Kararlarını Etkileyen Faktörlerin Analizi. Akademik Sosyal Araştırmalar Dergisi, Y11: 5, Sayı: 53, Eylül 2017, s. 257-277.

Wang, A. (2011). Younger Generations' Investing Behaviors in Mutual Funds: Does Gender Matter?. The journal of wealth management, 13(4), 13.

Wallach, M. A., \& Kogan, N. (1961). Aspects of judgment and decision making: Interrelationships and changes with age. Systems Research and Behavioral Science, 6(1), 23-36. 